\title{
Potentiation by vitamin D analogs of TNF $\alpha$ and ceramide-induced apoptosis in MCF-7 cells is associated with activation of cytosolic phospholipase $A_{2}$
}

\author{
Grisha Pirianov ${ }^{1}$, Carina Danielsson ${ }^{2}$, Carsten Carlberg ${ }^{2}$, \\ Sharon Y James ${ }^{1}$ and Kay W Colston ${ }^{*, 1}$ \\ 1 St. George's Hospital Medical School, Division of GEM, London, UK \\ 2 Institut fur Physiologische Chemie, Dusseldorf, Germany \\ * corresponding author: Kay Colston, St. George's Hospital, Medical School, \\ Department of Oncology, Gastroenterology, Endocrinology and Metabolism, \\ Cranmer Terrace, Tooting, London SW17 ORE, UK. tel: 0181-725-5887; \\ fax: 0181-682-0744; e-mail: k.colston@sghms.ac.uk
}

Received 22.02.99; revised 28.05.99; accepted 9.07.99 Edited by A. Finazzi-Agro

\begin{abstract}
Synthetic analogs of vitamin D induce apoptosis in cultured breast cancer cells and cause regression of experimentallyinduced rat mammary tumors. To further elucidate the mechanisms involved, we have examined interactions between two vitamin D analogs (CB1093 and EB1089) and known mediators of apoptosis, TNF $\alpha$ and ceramide. Pretreatment of MCF-7 breast cancer cells with CB1093 and EB1089 substantially potentiated cytotoxic effects of $T N F \alpha$ as assessed by cell viability assay, DNA fragmentation and videomicroscopy. No significant changes in the levels of TNF $\alpha$ or TNF-RI transcripts were detected. CB1093 primed cells demonstrated enhanced responsiveness to cell permeable $\mathrm{C}_{2}$-ceramide in terms of increased DNA fragmentation and loss of cell viability. Activation of cytosolic phospholipase $A_{2}$ $\left(\mathrm{CPLA}_{2}\right)$ has been implicated in TNF $\alpha$-mediated apoptosis. As assessed by $\left[{ }^{3} \mathrm{H}\right]$-arachidonic acid release, cells primed for $48 \mathrm{~h}$ with $\mathrm{CB} 1093$ (50 nM) showed enhanced CPLA $\mathrm{A}_{2}$ activation in response to TNF $\alpha$ or ceramide. CB1093 treatment alone led to $\mathrm{CPLA}_{2}$ activation and loss of cell viability which was inhibited by the specific inhibitor $\mathrm{AACOCF}_{3}$. These results suggest that TNF $\alpha$ and vitamin $D$ analogs share a common pathway leading to apoptosis involving $\mathrm{CPLA}_{2}$ activation and/ or ceramide generation.
\end{abstract}

Keywords: vitamin D analogs; breast cancer; cPLA ; ceramide; apoptosis; TNF $\alpha$

Abbreviations: CB1093, 20-epi-22(S)-ethoxy-23yne$24 \alpha, 26 \alpha, 27 \alpha$-trihomo-1 $\alpha, 25$-dihydroxyvitamin $D_{3}$; EB1089, 22,24diene-24 $\alpha, 26 \alpha, 27 \alpha$-trihomo-1 $\alpha, 25$-dixydroxyvitamin $\mathrm{D}_{3}$; TNF $\alpha$, tumor necrosis factor alpha; $c P L A_{2}$, cytosolic phospholipase $A_{2} ; A A$, arachidonic acid

\section{Introduction}

The active form of vitamin $D, 1,25$-dihydroxyvitamin $D_{3}$ $\left(1,25(\mathrm{OH})_{2} \mathrm{D}_{3}\right)$, has been shown to possess many properties unrelated to its classical functions in the control of bone and mineral metabolism. Furthermore, $1,25(\mathrm{OH})_{2} \mathrm{D}_{3}$ has been shown to inhibit growth and promote differentiation in a variety of normal and malignant cell types. ${ }^{1-4}$ The observation that a high proportion of breast tumor biopsy specimens contain receptors for $1,25(\mathrm{OH})_{2} \mathrm{D}_{3}$ and that the growth of cultured human breast cancer cells is inhibited in the presence of this vitamin $D$ metabolite led to the suggestion that vitamin $D$ derivatives might have potential as therapeutic agents in this and other malignancies. The use of conventional vitamin $D$ metabolites in this setting is limited by side effects such as hypercalcemia, hypercalciuria and soft tissue calcification. Synthetic vitamin D analogs have been developed which retain the ability to control cell proliferation and differentiation but display reduced calcemic activity relative to $1,25(\mathrm{OH})_{2} \mathrm{D}_{3}$ in vivo. ${ }^{5,6}$ In addition, a number of these compounds have been tested for their effectiveness in inhibiting the growth of breast cancer. ${ }^{7,8}$ We have carried out preclinical trials with a range of structurally modified compounds to assess effects on tumor growth in vivo using the rat model of hormone dependent breast cancer in which mammary tumors are induced with the carcinogen nitrosomethylurea. These studies demonstrated that a number of analogs including EB1089 and CB1093 cause regression of these experimental tumors. 9,10

Tumor regression occurs when the rate of cell death is greater than the rate of cell proliferation and more recent studies have shown that induction of apoptosis (programmed or active cell death) may be a feature of the anti-tumor effects of certain vitamin $D$ analogs. Several groups have presented evidence for the presence of DNA fragmentation, a key feature of apoptosis, in breast cancer cells treated with vitamin D derivatives. ${ }^{11-14}$ Mechanisms by which vitamin $D$ analogs promote apoptosis could involve suppression of cell survival signals and/or induction of genes that stimulate apoptosis. In the present study we have examined whether vitamin $D$ analogs may potentiate responsiveness of breast cancer cells to known mediators of apoptosis. TNF $\alpha$ is a potent cytokine which demonstrates anti-tumor activity both in vivo and in vitro and induces apoptosis in a variety of tumor cell lines. Of the two TNF receptors, TNF-RI (p55) and TNF-RII (p75), the former is thought to promote cytotoxic effects. The binding of TNF $\alpha$ to its receptors is necessary but not sufficient for its cytotoxic action. ${ }^{15,16}$ The signal transduction pathways involved in TNF $\alpha$-mediated cell 
death are obscure but these receptors are assumed to transduce signals across the plasma membrane. Studies have showed that the TNF-RI death domain specifically interacts with the intracellular adaptor protein TRADD, which in turn associates with another adaptor protein FADD/MORT1 and the newly formed complex can interact and activate caspase-8/FLICE leading to induction of apoptosis. ${ }^{17,18}$

The sphingomyelin pathway mediates signaling for apoptosis induced by several agents including TNF $\alpha{ }^{19,20}$ Activation of sphingomyelinases hydrolyses sphingomyelin to generate ceramide which acts as a second
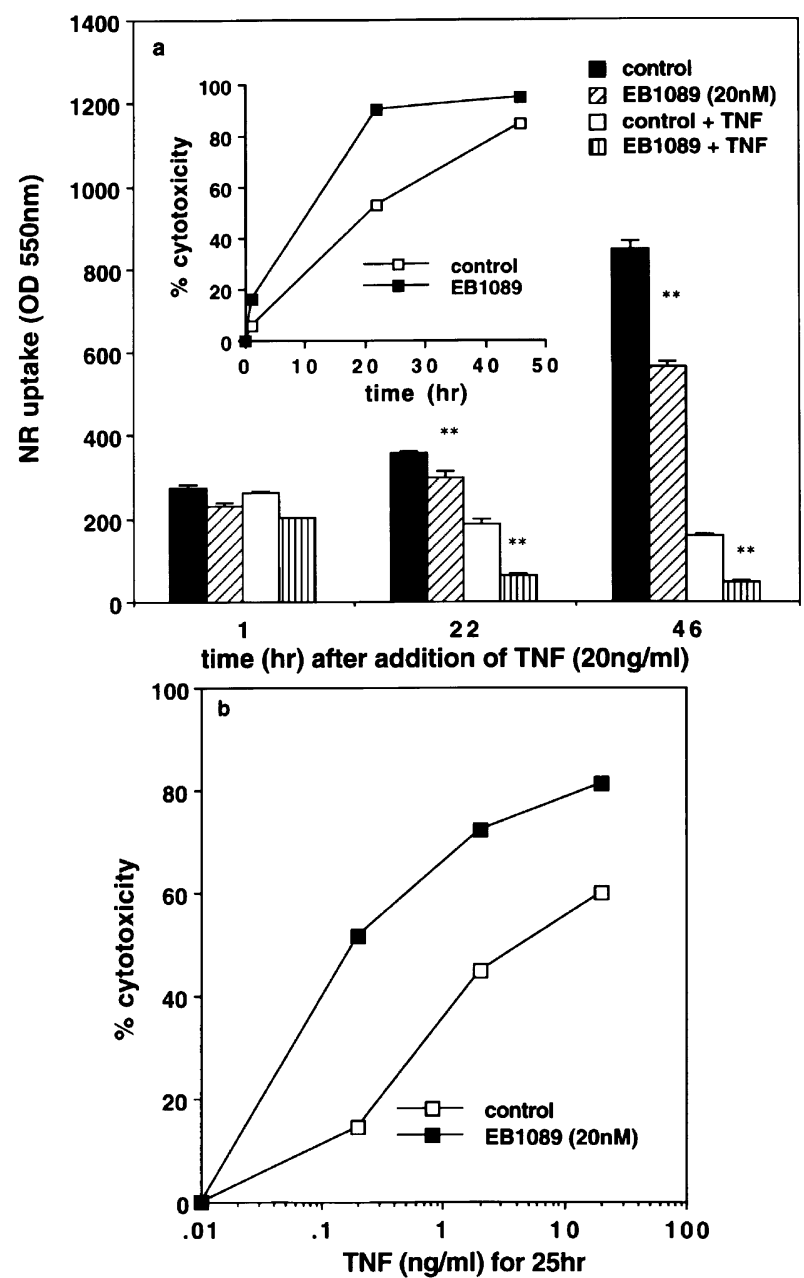

Figure 1 (a) Effects of pretreatment with vitamin D analog EB1089 on TNF $\alpha$ induced cytotoxicity in MCF-7 cells. Cells were plated in 24 well plates and treated for $67 \mathrm{~h}$ with $20 \mathrm{nM}$ EB1089 or ethanol vehicle followed by posttreatment with $20 \mathrm{ng} / \mathrm{ml} \mathrm{TNF} \alpha$ for up to $46 \mathrm{~h}$. Results are expressed as mean \pm S.E.M. of six replicate cultures. Percentage cytotoxicity was determined by neutral red dye assay as described in Materials and Methods. The difference between cultures treated with TNF $\alpha$ alone and TNF $\alpha$ plus EB1089 was significant at 22 and $46 \mathrm{~h}\left({ }^{* *} P<0.001\right)$. Differences between control and EB1089 treated cultures were significant at 22 and $46 \mathrm{~h}$ $\left.{ }^{* *} P<0.001\right)$. (b) Effects of increasing concentrations of TNF $\alpha$ on MCF-7 cell viability in cultures pretreated with EB1089. Cells were plated in 24 well plates and treated for $67 \mathrm{~h}$ with $20 \mathrm{nM}$ EB1089 or ethanol vehicle followed by posttreatment with increasing concentrations of TNF $\alpha$ for $25 \mathrm{~h}$ messenger in distinct signaling pathways such as cell proliferation and apoptosis. ${ }^{20-22}$ Cytosolic phospholipase $\mathrm{A}_{2}$ (cPLA $\mathrm{A}_{2}$ or $\mathrm{PLA}_{2}$-IV isoform) is involved in arachidonic acid (AA) release from its cellular storage in the phospholipid pool and plays an important role in cellular signaling (cellular proliferation and inflammation). ${ }^{23,24}$ As with ceramide, it has been documented that activation of

a)

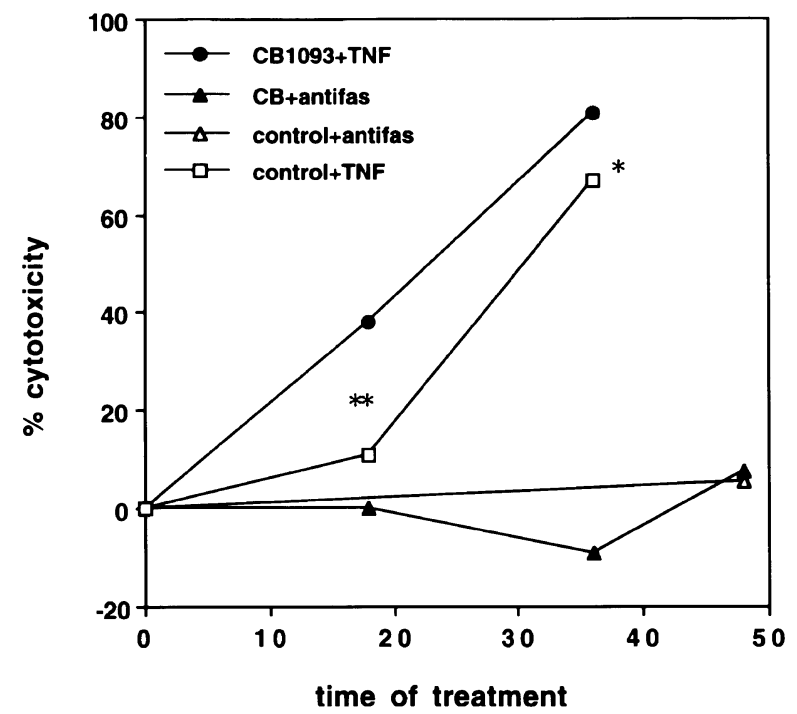

b)

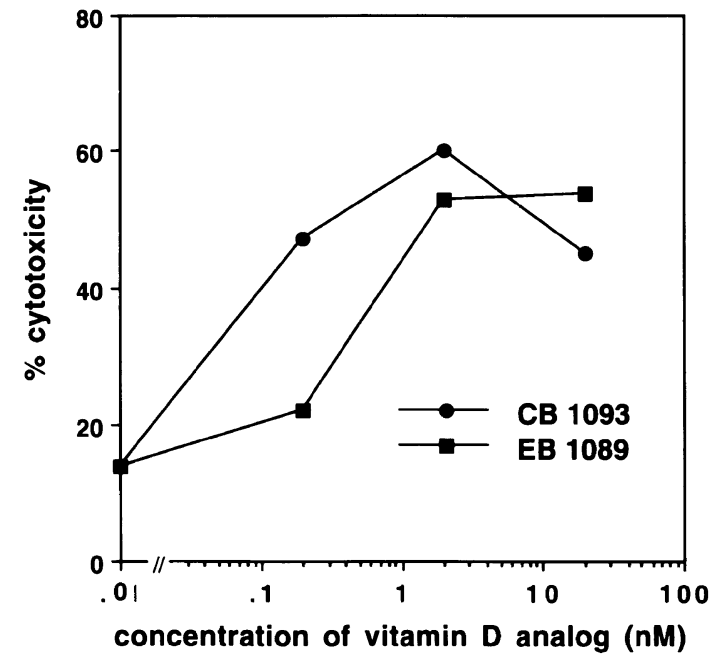

Figure 2 (a) Effect of pretreatment with vitamin D analogs on TNF $\alpha$-induced cytotoxicity in MCF-7 cells. Cells were primed for $24 \mathrm{~h}$ with $20 \mathrm{nM} \mathrm{CB} 1093$ and then post treated with TNF $\alpha(5 \mathrm{ng} / \mathrm{ml})$ or anti-Fas $(250 \mathrm{ng} / \mathrm{ml})$ for up to $48 \mathrm{~h}$. Differences between cultures treated with TNF $\alpha$ alone and CB1093 plus TNF $\alpha$ were significant at 18 and $36 \mathrm{~h}\left({ }^{*} P<0.001\right.$ and ${ }^{*} P<0.01$ respectively). Results are representative of three separate experiments. (b) Dose dependent effect of vitamin D analogs on TNF $\alpha$-induced cytotoxicity. Cells were plated into 24 well plates and treated with increasing concentrations of EB1089 or $\mathrm{CB} 1093$ for $65 \mathrm{~h}$ followed by post-treatment with $10 \mathrm{ng} / \mathrm{ml}$ TNF $\alpha$. Percentage cytotoxicity was determined by neutral red dye assay as described in Materials and Methods with six replicate cultures per treatment group. Results are representative of at least four separate experiments 
$\mathrm{CPLA}_{2}$ and release of $\mathrm{AA}$ as a second messenger is implicated in distinct signaling of TNF $\alpha$-mediated apoptosis in several cell lines including MCF-7 cells. CPLA 2 is normally located in the cytoplasm and it translocates to the cell membrane in a calcium dependent or independent manner. ${ }^{25,26}$ In order to define the cellular and molecular mechanisms involved in vitamin D-induced apoptosis in breast cancer cells, we have assessed the effects of two vitamin D analogs EB1089 and CB1093 on TNF $\alpha$-induced apoptosis in MCF-7 cells. We now report that these vitamin $\mathrm{D}$ analogs potentiate responsiveness of breast cancer cells to $\mathrm{TNF} \alpha$ and suggest that ceramide and/or $\mathrm{CPLA}_{2}$ might be involved in a common pathway in $\mathrm{TNF} \alpha$ and vitamin $\mathrm{D}$ mediated apoptosis.

\section{Results}

\section{Vitamin D analogs potentiate the cytotoxic effects of TNF $\alpha$}

The cytotoxic effect of TNF $\alpha$ on MCF-7 cells and its modulation by synthetic vitamin $D$ analogs is shown in Figures 1 and 2 . MCF-7 cells were found to be responsive to induction of apoptosis by TNF $\alpha$ and this cytotoxic effect was augmented in cultures pretreated with the vitamin D analogs EB1089 and CB1093. Initially, the time course of TNF $\alpha$-induced cytotoxicity in the presence or absence of the vitamin D analogs EB1089 and CB1093 was determined. As shown in Figure 1a, MCF-7 cell cultures preincubated with $20 \mathrm{nM}$ EB1089 for $67 \mathrm{~h}$ and subsequently treated with $20 \mathrm{ng} / \mathrm{ml} \mathrm{TNF} \alpha$ achieved $90 \%$ cytotoxicity $22 \mathrm{~h}$ after addition of the cytokine, compared to (a)

\section{VITAMIN D ANALOGUE CB1093 POTENTIATES TNF-alpha-INDUCED CYTOTOXICITY IN MCF-7 BREAST CANCER CELLS}
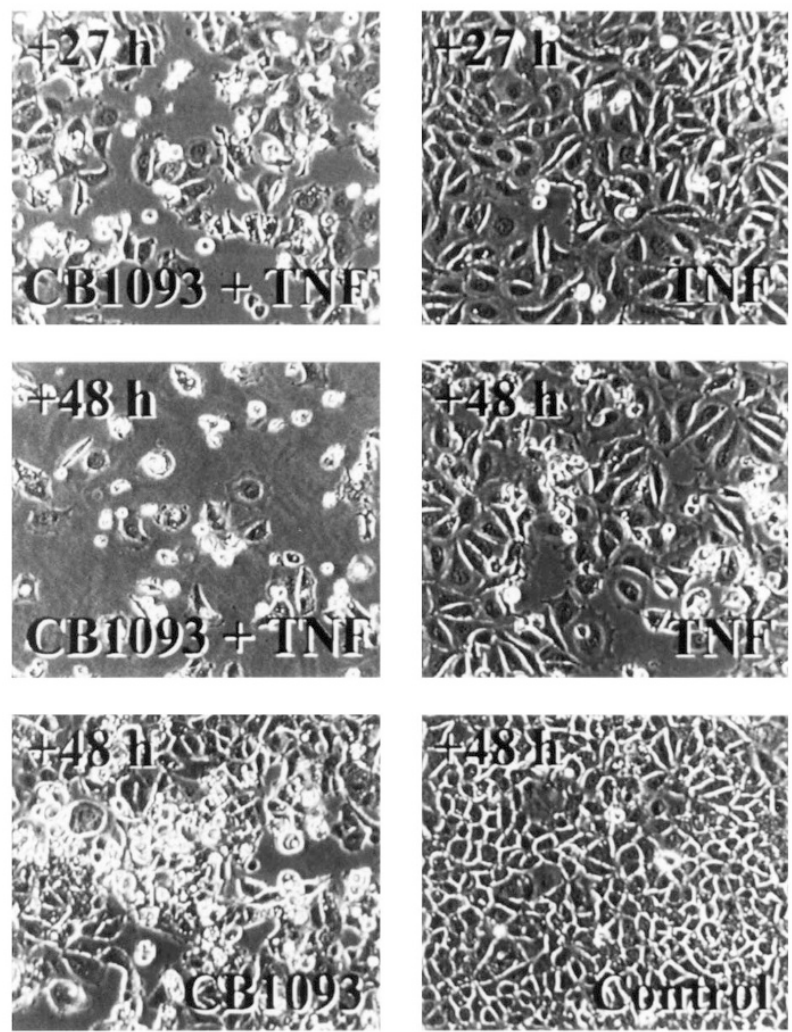

(b)

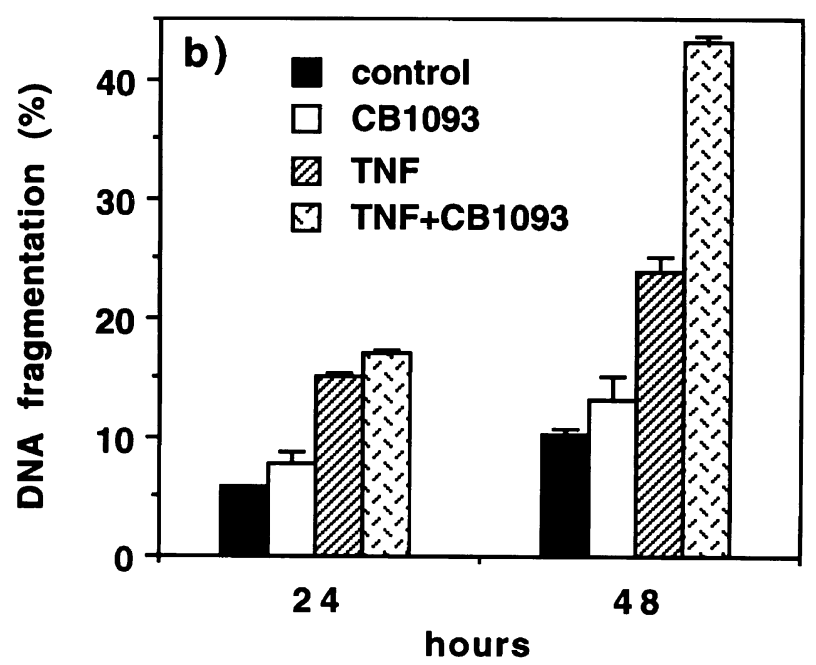

Figure 3 Videomicroscopy of apoptosis and DNA fragmentation in MCF-7 cells treated with CB1093 and TNF $\alpha$. (a) MCF-7 cells were seeded in T25 tissue culture flasks and treated for $42 \mathrm{~h}$ with $25 \mathrm{nM} \mathrm{CB} 1093$ or ethanol vehicle. TNF $\alpha(10 \mathrm{ng} / \mathrm{ml})$ was then added and cultures were incubated for a further $48 \mathrm{~h}$. Typical fields from CB1093/TNF $\alpha$ (left top and middle panels) and control/TNF $\alpha$ treated cultures (right top and middle panels) were photographed over this period at 1/150 normal speed with a time-lapse videorecorder. At $48 \mathrm{~h}$ typical fields from control (right lower panel) and cultures treated with CB1093 alone (left lower panel) were similarly photographed. (b) MCF-7 cells were labeled with [ ${ }^{3} \mathrm{H}$-methyl]-thymidine $(0.5 \mu \mathrm{Ci} / \mathrm{ml})$ for $24 \mathrm{~h}$, washed twice and then pretreated with $\mathrm{CB} 1093$ and finally exposed to TNF $\alpha$ for 24 and $48 \mathrm{~h}$ and assessed for DNA fragmentation as described in Materials and Methods. Results are the mean \pm S.D. of three replicate estimations and are representative of three separate experiments 
$53 \%$ cytotoxicity seen with cultures preincubated in the absence of the vitamin $D$ analog. In addition to reducing the time required to achieve substantial cytotoxicity, pretreatment with the vitamin $\mathrm{D}$ analogs led to a reduction in concentration of the cytokine required to induce significant cell death as illustrated in Figure 1b. Pretreatment of cells with $20 \mathrm{nM}$ EB1089 for $67 \mathrm{~h}$ reduced the concentration of TNF $\alpha$ required for $50 \%$ cytotoxicity from $4-0.2 \mathrm{ng} / \mathrm{ml}$. Similar potentiation of TNF $\alpha$-induced cytotoxicity was seen in cultures pretreated with $20 \mathrm{nM}$ CB1093 for $24 \mathrm{~h}$ and post-treated with $10 \mathrm{ng} / \mathrm{ml}$ TNF $\alpha$ for up to $36 \mathrm{~h}$. However, no substantial cytotoxicity was seen with control or CB1093-primed cells exposed to $250 \mathrm{ng} / \mathrm{ml}$ anti-
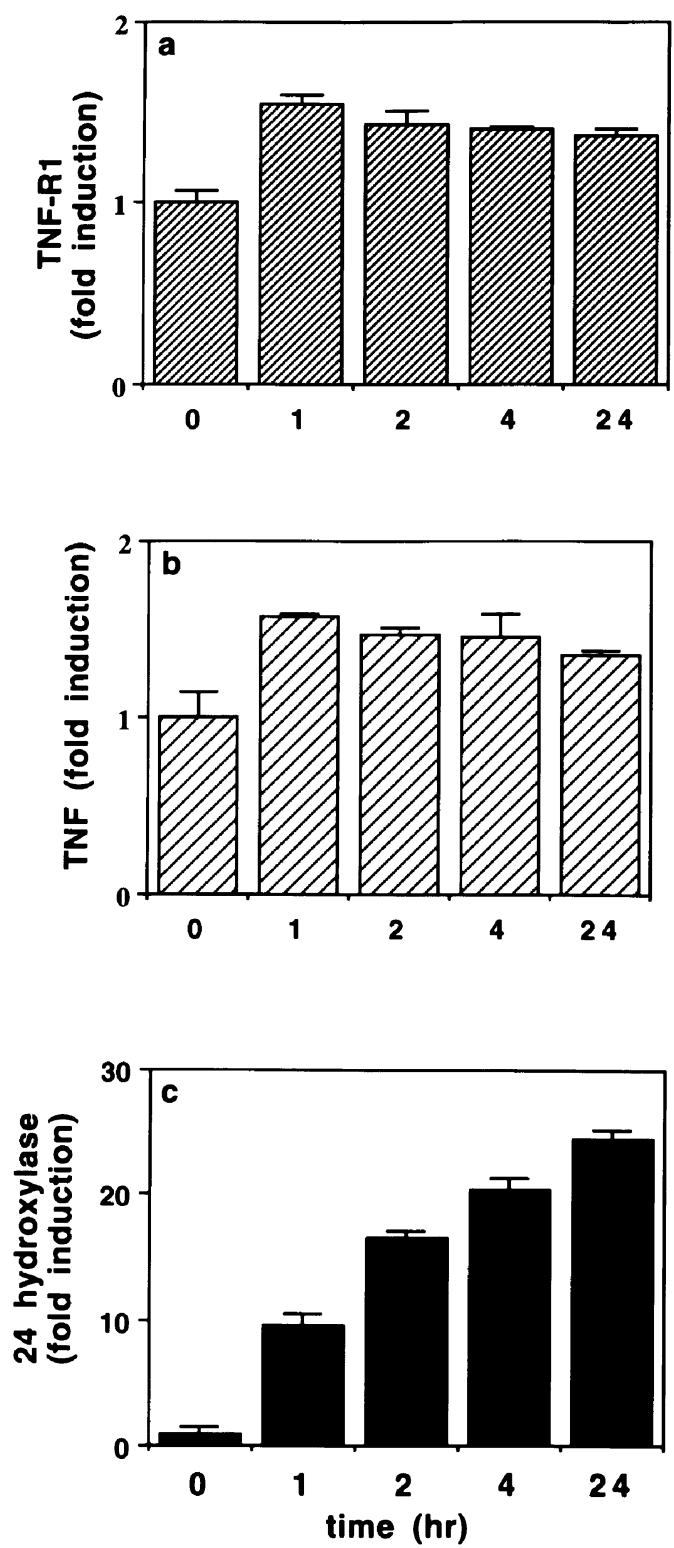

Figure 4 TNF $\alpha$, TNFR-I and 24-hydroxylase mRNA expression in MCF-7 cells. Cells were treated with CB1093 for 1, 2, 4 and $24 \mathrm{~h}$ and harvested. Levels of expressed TNF-RI (a), TNF $\alpha$ (b) and 24-hydroxylase mRNA (c) were obtained by semi-quantitative RT-PCR in relation to $\beta 2$ microglobulin mRNA expression. Data shown are based on three separate RNA preparations per treatment condition and $\mathrm{PCR}$ reactions were performed in duplicate
Fas for up to $48 \mathrm{~h}$ (Figure 2a). Regarding the relative potency of the two vitamin $D$ analogs in potentiating TNF $\alpha$-induced apoptosis, Figure $2 \mathrm{~b}$ demonstrates that CB1093 is more effective than EB1089 in promoting responsiveness to the cytokine. Following post-treatment with $10 \mathrm{ng} / \mathrm{ml} \mathrm{TNF} \alpha$ for $23 \mathrm{~h}, 50 \%$ cytotoxicity was observed in cells pretreated with $0.3 \mathrm{nM}$ CB1093 compared to $1.6 \mathrm{nM}$ EB1089. This order of potency is similar to that which we have observed with CB1093 and EB1089 in inducing active cell death in MCF-7 cells after 5 days of treatment with the vitamin $D$ analogs alone. ${ }^{10}$ Videomicroscopy confirmed that the accelerated loss of cell viability in cultures pretreated with vitamin $D$ analogs was due to apoptosis. Following $27 \mathrm{~h}$ exposure of CB1093-primed cultures to TNF $\alpha$, morphological features of active cell death were observed including detachment and cell shrinkage (Figure 3a). Furthermore data obtained from DNA fragmentation analysis correlated well with videomicroscopy. CB1093primed MCF-7 cells demonstrated enhanced responsiveness to TNF $\alpha$ in terms of increased levels of TNF $\alpha$-induced DNA fragmentation at 24 or $48 \mathrm{~h}$ respectively (Figure $3 \mathrm{~b}$ ). We next assessed the minimum time of pretreatment with the vitamin $D$ analogs which is required to observe potentiation of TNF $\alpha$ cytotoxicity. Addition of 20 nM EB1089 or CB1093 $2 \mathrm{~h}$ prior to $\mathrm{TNF} \alpha$ treatment yielded similar potentiation to that seen with $24 \mathrm{~h}$ pretreatment (data are not shown). No significant enhancement of TNF $\alpha$ effects was seen when the analogs were added $17.5 \mathrm{~h}$ after the cytokine.

\section{Effects of CB1093 on TNF-RI and endogenous TNF $\alpha$ expression}

To determine if the mechanism by which vitamin $D$ analogs enhance responsiveness to the cytokine occurred by promoting recognition of the TNF $\alpha$ signal, effects on expression of TNF-RI were examined at the mRNA level. MCF-7 cell cultures were treated with ethanol vehicle or CB1093 (100 nM) for 1-24 $\mathrm{h}$ and level of induction of TNF-RI transcripts determined by RT-PCR. Only a modest ( 1.5 fold) increase in the induction of TNF-RI transcripts was observed at $1 \mathrm{~h}$ in comparison to a tenfold induction of 25 hydroxyvitamin $D_{3}$-24-hydroxylase, a gene previously demonstrated to be induced by $1,25(\mathrm{OH})_{2} \mathrm{D}_{3}$ and its analogs. ${ }^{27}$ Levels of 24-hydroxylase transcripts increased over a $24 \mathrm{~h}$ period but no further increase in TNF-RI mRNA was observed (Figure $4 a, c)$. The above studies suggest that the potentiation of TNF $\alpha$ actions by vitamin $D$ analogs is unlikely to be through enhanced recognition of the TNF $\alpha$ signal. We next sought to determine if vitamin $D$ analogs may enhance autocrine production of TNF $\alpha$. MCF-7 cell cultures were treated with ethanol vehicle or CB1093 (100 nM) for 1-24 $\mathrm{h}$ and level of induction of TNF $\alpha$ transcripts determined by RT-PCR. As with TNF-RI, an approximately 1.5 fold increase in the induction of $\mathrm{TNF} \alpha$ transcripts was observed after $1 \mathrm{~h}$ of CB1093 treatment which was maintained for up to $4 \mathrm{~h}$ (Figure 4b). To further investigate whether pretreatment with vitamin $\mathrm{D}$ analogs may increase autocrine production of TNF $\alpha, \mathrm{MCF}-7$ cell cultures were treated with ethanol vehicle, CB1093 or TNF $\alpha$ for 5 days. Conditioned medium from these cultures was collected and analyzed in a cytotoxicity assay using the highly TNF $\alpha$-sensitive cell line WEHI 164 clone 13. Medium 
was conditioned between days 3-5 of treatment. To eliminate possible direct inhibitory effects of CB1093 present in conditioned medium on the cytotoxicity assay target WEHI cells, parallel cultures received the agents for days $0-3$ of treatment only and then fresh medium without these additions was added for days $3-5$ and TNF $\alpha$-like bioactivity in 3-5 days conditioned medium assessed by cytotoxicity assay. No evidence of increased TNF $\alpha$ secretion in CB1093 treated cells was observed and levels of TNF $\alpha$-like activity were below the detection limit of the bioassay $(250 \mathrm{fg} / \mathrm{ml}$, Table 1$)$.

\section{CB1093 promotes $\mathrm{C}_{2}$-ceramide-induced cytotoxicity in MCF-7 cells}

A possible mechanism by which vitamin $D$ analogs may potentiate TNF $\alpha$-induced cytotoxicity is by promotion of a common apoptotic pathway. Generation of ceramide through hydrolysis of sphingomyelin appears to play a role in TNF $\alpha$ induced apoptosis. We next determined if pretreatment with CB1093 could modulate this step in the TNF $\alpha$ signaling pathway. MCF-7 cells were pretreated with CB1093 (50 nM for $48 \mathrm{~h}$ ) and exposed to cell permeable $\mathrm{C}_{2}$-ceramide $(0.5-$ $20 \mu \mathrm{M}$ for $24 \mathrm{~h}$ ) before DNA fragmentation assay. CB1093 augmented both the level of $\mathrm{C}_{2}$-ceramide-induced intranucleosomal DNA fragmentation and loss of cell viability (Figure $5 a, b)$.

\section{CB1093 potentiates effect of $\mathrm{TNF} \alpha$ on activation of CPLA $_{2}$}

In some cells, TNF $\alpha$-mediated killing is accompanied by activation of $\mathrm{cPLA}_{2}$. Arachidonic acid generated as a result

Table 1 Effects of CB1093 and TNF $\alpha$ on MCF-7 cell viability and TNF $\alpha$-like bioactivity in MCF-7 cell conditioned medium

\begin{tabular}{|c|c|c|}
\hline & $\begin{array}{c}\text { MCF-7 cell viability } \\
\text { (NR uptake OD } \\
550 \mathrm{~nm} \text { ) }\end{array}$ & $\begin{array}{c}\text { Viability of WEHI cells } \\
\text { incubated with MCF-7 } \\
\mathrm{CM}^{\circ} \% \text { control } / \mathrm{TNF}^{+}\end{array}$ \\
\hline \multicolumn{3}{|c|}{ (a) Treated $0-5$ days (CM $3-5$ days) } \\
\hline Control & $1.134 \pm 0.14^{\mathrm{a}}$ & $100.6 \pm 8.3 / \mathrm{ND}^{\mathrm{a}}$ \\
\hline CB1093 & $0.345 \pm 0.049^{\star \star \star}$ & $98.5 \pm 6.49 / N D$ \\
\hline TNF & $0.952 \pm 0.068^{\star}$ & $60.4 \pm 8.33^{\star * *} / 1.3 \mathrm{pg} / \mathrm{ml}$ \\
\hline TNF+CB1093 & $0.276 \pm 0.036^{\star \star *}$ & $61.1 \pm 7.0^{\star * *} / 1.1 \mathrm{pg} / \mathrm{ml}$ \\
\hline \multicolumn{3}{|c|}{ (b) Treated $0-3$ days (CM $3-5$ days) } \\
\hline Control & $1.167 \pm 0.10$ & $95.3 \pm 7.2 / \mathrm{ND}$ \\
\hline CB1093 & $0.268 \pm 0.052^{\star \star \star}$ & $99.9 \pm 12.8 / \mathrm{ND}$ \\
\hline TNF & $0.861 \pm 0.081^{\star \star \star}$ & $91.8 \pm 8.5 / \mathrm{ND}$ \\
\hline TNF+CB1093 & $0.249 \pm 0.024^{\star \star \star}$ & $93.9 \pm 6.3 / \mathrm{ND}$ \\
\hline
\end{tabular}

Medium conditioned by control (ethanol vehicle), CB1093 (50 nM) and TNF $\alpha$ $(0.1 \mathrm{ng} / \mathrm{ml})$ treated cells was assessed in a $20 \mathrm{~h}$ cytotoxicity assay using the highly TNF-sensitive cell line WEHI $164 \mathrm{cl}$ 13. (a) MCF-7 cells were plated in 24 well plates as described in Materials and Methods. Cultures were treated for 5 days with CB1093, TNF or these agents in combination with a medium change on day 3. TNF-like bioactivity in 3-5 day conditioned medium was assessed by bioassay. (b) To eliminate possible direct inhibitory effect of CB1093 on the cytotoxic assay target WEHI cells, parallel cultures received the agents for days $0-3$ of treatment and then fresh medium without these additions was added for days $3-5$. TNF-like bioactivity in 3-5 day conditioned medium was assessed by bioassay. ${ }^{\mathrm{a}}$ Mean + S.E.M. of six replicate cultures. Significantly different from respective controls. ${ }^{* * *} P<0.0001,{ }^{*} P<0.005$. ${ }^{\wedge}$ control cultures incubated with non-conditioned medium ${ }^{+}$TNF concentration calculated from bioassay in relation to rhTNF $\alpha$ standard. ND=no TNF-like bioactivity detected. Detection limit of this assay is $250 \mathrm{fg} / \mathrm{ml}$ of $\mathrm{CPLA}_{2}$ activation has been implicated in a signal transduction pathway resulting in cell death. ${ }^{25,28}$ To investigate the possible role of $\mathrm{CPLA}_{2}$ activation in the potentiation of TNF $\alpha$ effects by vitamin D analogs, MCF-7 cells were pretreated with CB1093 (50 nM for $48 \mathrm{~h}$ ) and then labeled with $\left[{ }^{3} \mathrm{H}\right]-\mathrm{AA}(0.3 \mu \mathrm{Ci} / \mathrm{ml})$ for $18 \mathrm{~h}$, washed and post-treated with TNF $\alpha(0-10 \mathrm{ng} / \mathrm{ml})$ for a further $20 \mathrm{~h}$. A dose related increase in the activation of $\mathrm{CPLA}_{2}$, as assessed by $\left[{ }^{3} \mathrm{H}\right]-\mathrm{AA}$ release, was observed with TNF $\alpha$ which was potentiated when cells were pretreated with
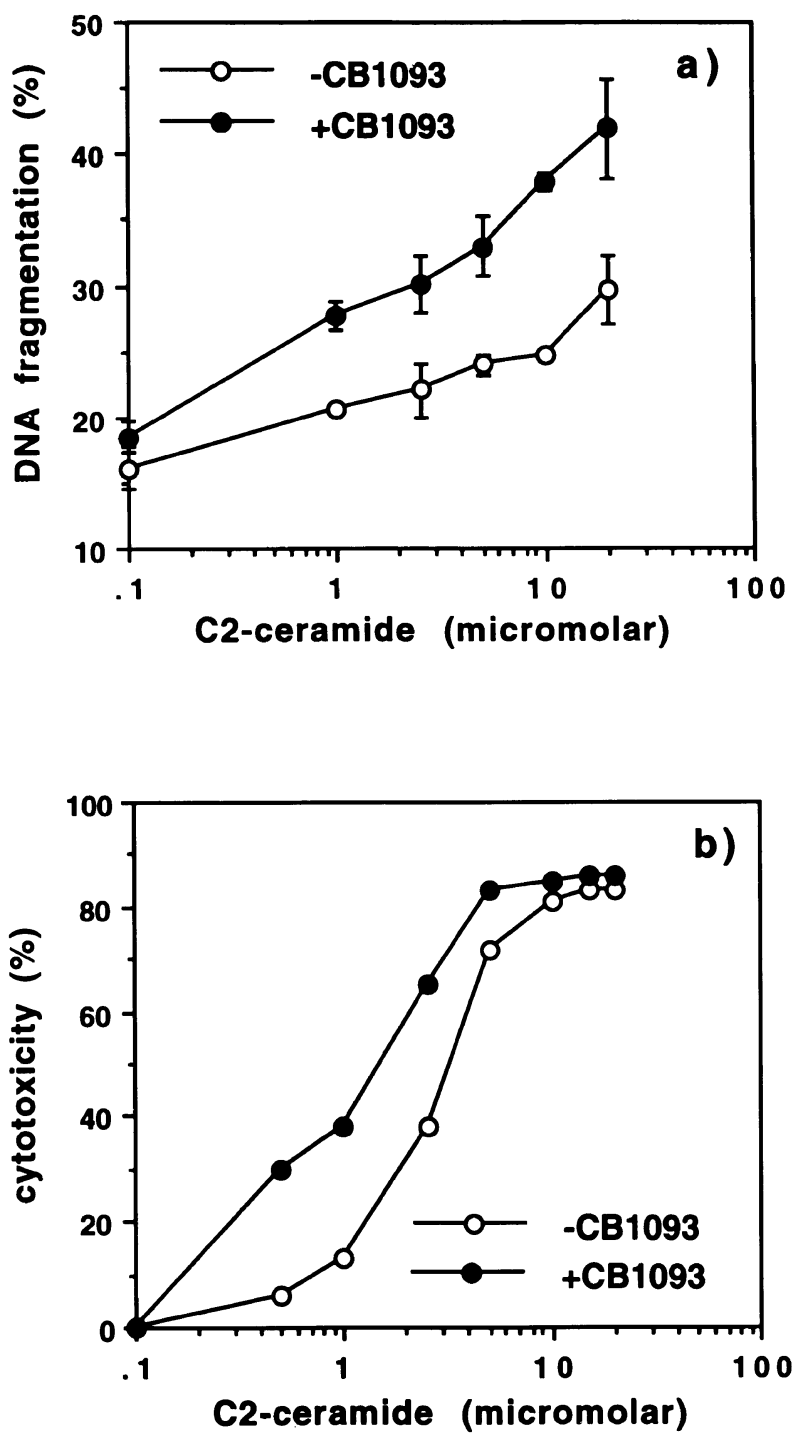

Figure 5 CB1093 promotes $\mathrm{C}_{2}$-ceramide-induced apoptosis and loss of cell viability in MCF-7 breast cancer cells. (a) MCF-7 cells were labeled with $\left[{ }^{3} \mathrm{H}\right.$ methyl-thymidine $(0.5 \mu \mathrm{Ci} / \mathrm{ml})$ for $24 \mathrm{~h}$, washed twice and then exposed to cell permeable $\mathrm{C}_{2}$-ceramide $(0.5-20 \mu \mathrm{M})$ for a further $24 \mathrm{~h}$ and assessed for DNA fragmentation as described in Materials and Methods. (b) MCF-7 cells were pre-incubated with CB1093 (50 nM for $48 \mathrm{~h}$ ), washed and then exposed to cell permeable $\mathrm{C}_{2}$-ceramide $(0.5-20 \mu \mathrm{M})$ for $24 \mathrm{~h}$ and assessed for cell viability by neutral red assay as described in Materials and Methods. Results are the mean \pm S.D. of three replicate estimations and are representative of three separate experiments 
CB1093 (Figure 6a). The activation of $\mathrm{CPLA}_{2}$ and its enhancement by $\mathrm{CB} 1093$ was inversely related to cell viability as determined by neutral red assay (Figure 6b). The relationship of $\mathrm{CPLA}_{2}$ to potentiation of TNF $\alpha$-induced cytotoxicity to CB1093 was determined by cotreating CB1093-primed cells with $\operatorname{TNF} \alpha(0-10 \mathrm{ng} / \mathrm{ml})$ and the specific $\mathrm{CPLA}_{2}$ inhibitor $\mathrm{AACOCF}_{3}$. Results showed that this inhibitor limited induced $\mathrm{CPLA}_{2}$ potentiation of both CB1093 and TNF $\alpha$ in CB1093-primed MCF-7 cells (Figure $6 a, b)$.

\section{$\mathrm{C}_{2}$-ceramide activation of $\mathrm{CPLA}_{2}$ is enhanced by CB1093}

Since it has been suggested that arachidonic acid released during $\mathrm{CPLA}_{2}$ activation may act as a second messenger to activate other apoptosis associated
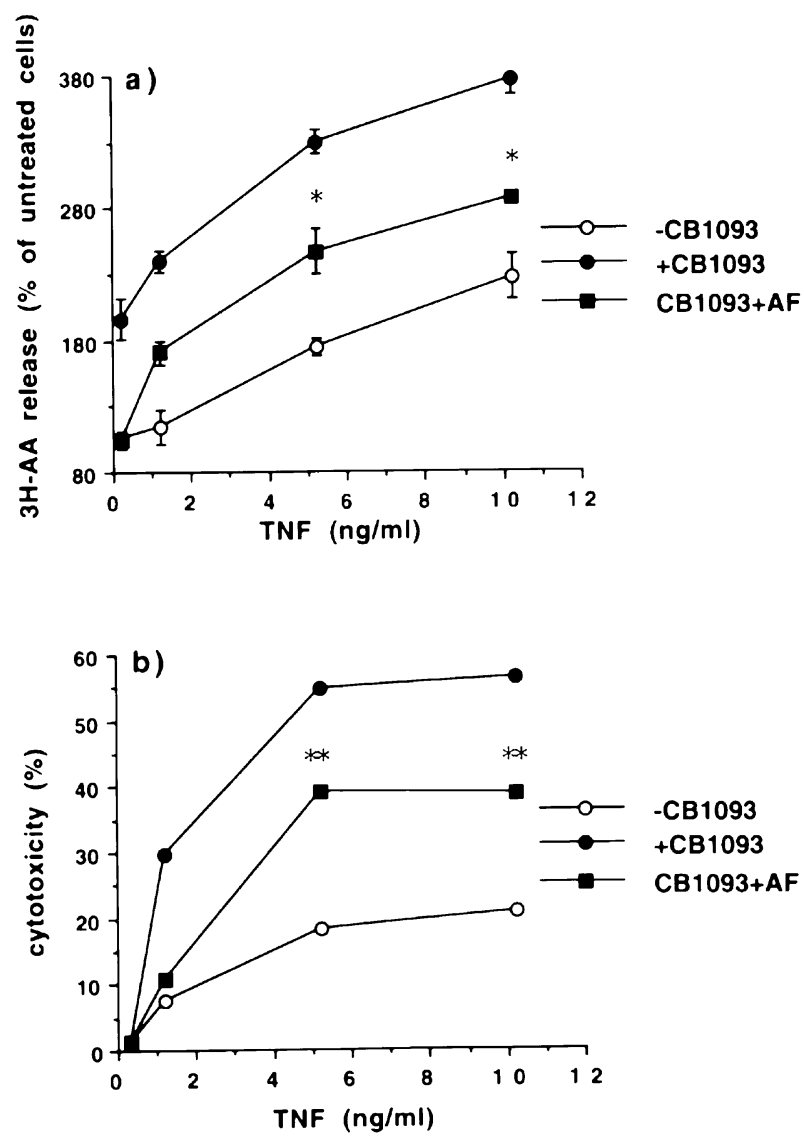

Figure 6 Effect of $\mathrm{CB} 1093$ and TNF $\alpha$ on activation of $\mathrm{CPLA} \mathrm{A}_{2}$ in MCF-7 breast cancer cells. (a) MCF-7 cells were pretreated with CB1093 ( $50 \mathrm{nM}$ for $48 \mathrm{~h}$ ) and labeled with $\left[{ }^{3} \mathrm{H}\right]-\mathrm{AA}(0.3 \mu \mathrm{Ci} / \mathrm{ml})$ for $18 \mathrm{~h}$, washed and post-incubated with or without $5 \mu \mathrm{M} \mathrm{AACOCF}{ }_{3}$ (AF) for $3 \mathrm{~h}$ and finally exposed to TNF $\alpha(0-10 \mathrm{ng} / \mathrm{ml})$ for further $18 \mathrm{~h}$. CPLA 2 activation was assessed by ${ }^{3}[\mathrm{H}]-\mathrm{AA}$ release as described in Materials and Methods. (b) Replicate cultures were assessed for cytotoxicity by neutral red assay, as described in Materials and Methods. Statistical comparison between CB1093 and TNF $\alpha$ alone or CB1093 and TNF $\alpha$ plus $\mathrm{AACOCF}_{3}$ was found to be significant at ${ }^{*} P<0.05$ and ${ }^{* *} P<0.001$. Results are the mean \pm S.D. of three replicate estimations and are representative of three separate experiments enzymes such as sphingomyelinase leading to the generation of ceramide, we sought to identify the relationship of $\mathrm{cPLA}_{2}$ activation to ceramide-induced apoptosis. To this end, MCF-7 cells were labeled with $\left[{ }^{3} \mathrm{H}\right]-\mathrm{AA}$ and then exposed to membrane permeable $\mathrm{C}_{2}$ ceramide for $4 \mathrm{~h}$ and $\mathrm{CPLA}_{2}$ activity assayed as previously described. Our results clearly show that incubation of MCF-7 cells with $\mathrm{C}_{2}$-ceramide leads to a dose dependent activation of $\mathrm{cPLA}_{2}$ (Figure 7a), suggesting that this enzyme may act down stream of ceramide generation in the apoptotic cascade. Activation
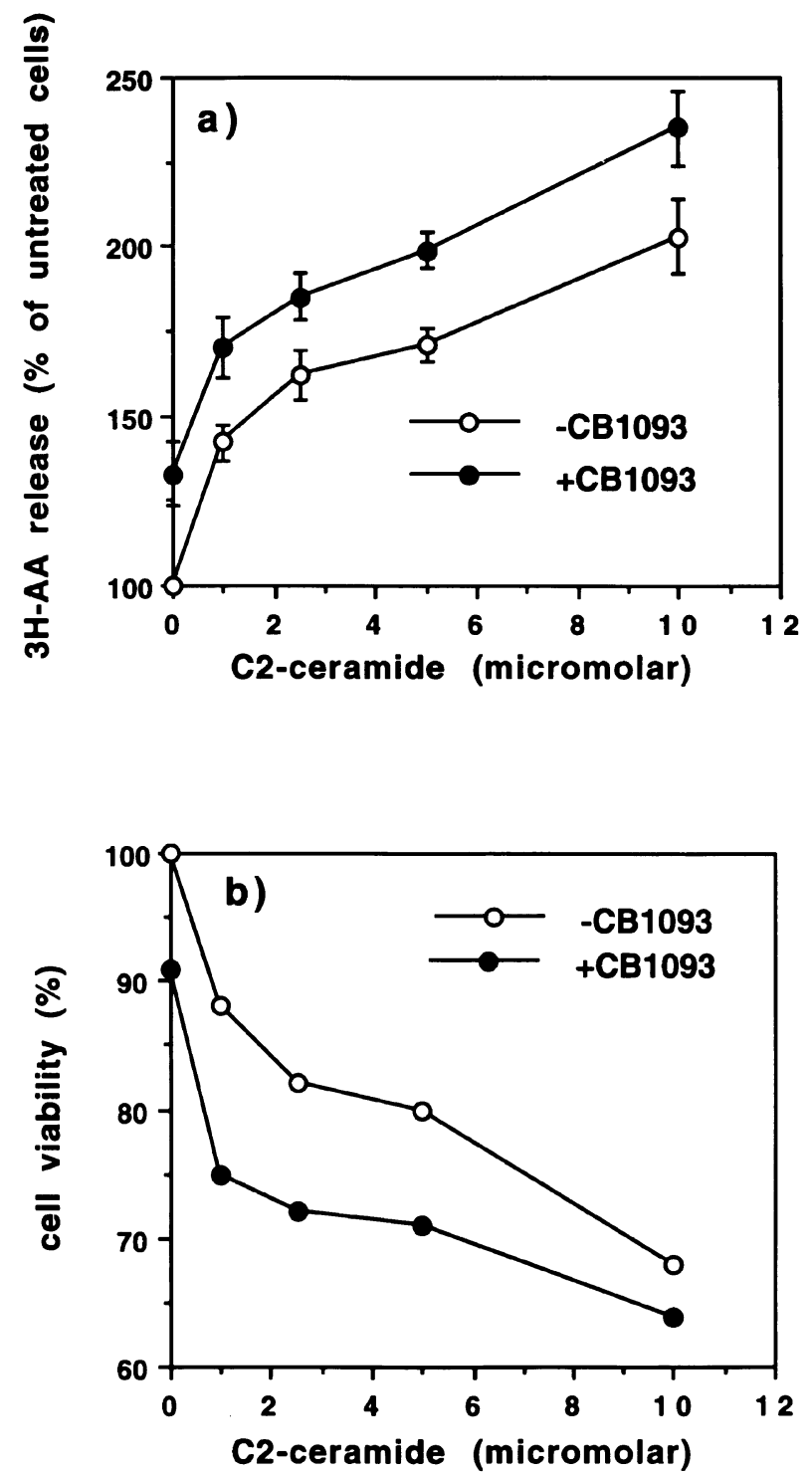

Figure 7 CB1093 promotes $\mathrm{C}_{2}$-ceramide-induced activation of $\mathrm{CPLA}$ and loss of cell viability in MCF-7 cells. (a) Cells were pretreated with CB1093 ( $50 \mathrm{nM}$ for $48 \mathrm{~h})$ and labeled with $\left[{ }^{3} \mathrm{H}\right]-\mathrm{AA}(0.3 \mu \mathrm{Ci} / \mathrm{ml})$ for $18 \mathrm{~h}$, washed and exposed to $\mathrm{C}_{2}$-ceramide $(0-20 \mu \mathrm{M})$ for further $5 \mathrm{~h}$. $\mathrm{CPLA}_{2}$ activation was assessed by $\left[{ }^{3} \mathrm{H}\right]-\mathrm{AA}$ release as described in Materials and Methods. (b) Replicate cultures were assessed for cell viability by MTS assay, as described in Materials and Methods. Results are the mean \pm S.D. of three replicate estimations and are representative of three separate experiments 
of $\mathrm{CPLA}_{2}$ in response to $\mathrm{C}_{2}$-ceramide is more rapid than with TNF $\alpha$ being evident $4 \mathrm{~h}$ after cells are exposed to $\mathrm{C}_{2}$-ceramide in comparison to $20 \mathrm{~h}$ with $\mathrm{TNF} \alpha$. Furthermore, cells primed for $48 \mathrm{~h}$ with CB1093 show enhanced $\mathrm{CPLA}_{2}$ activation in response to ceramide. Cell viability was inversely correlated with $\mathrm{CPLA}_{2}$ activation (Figure $7 b)$.
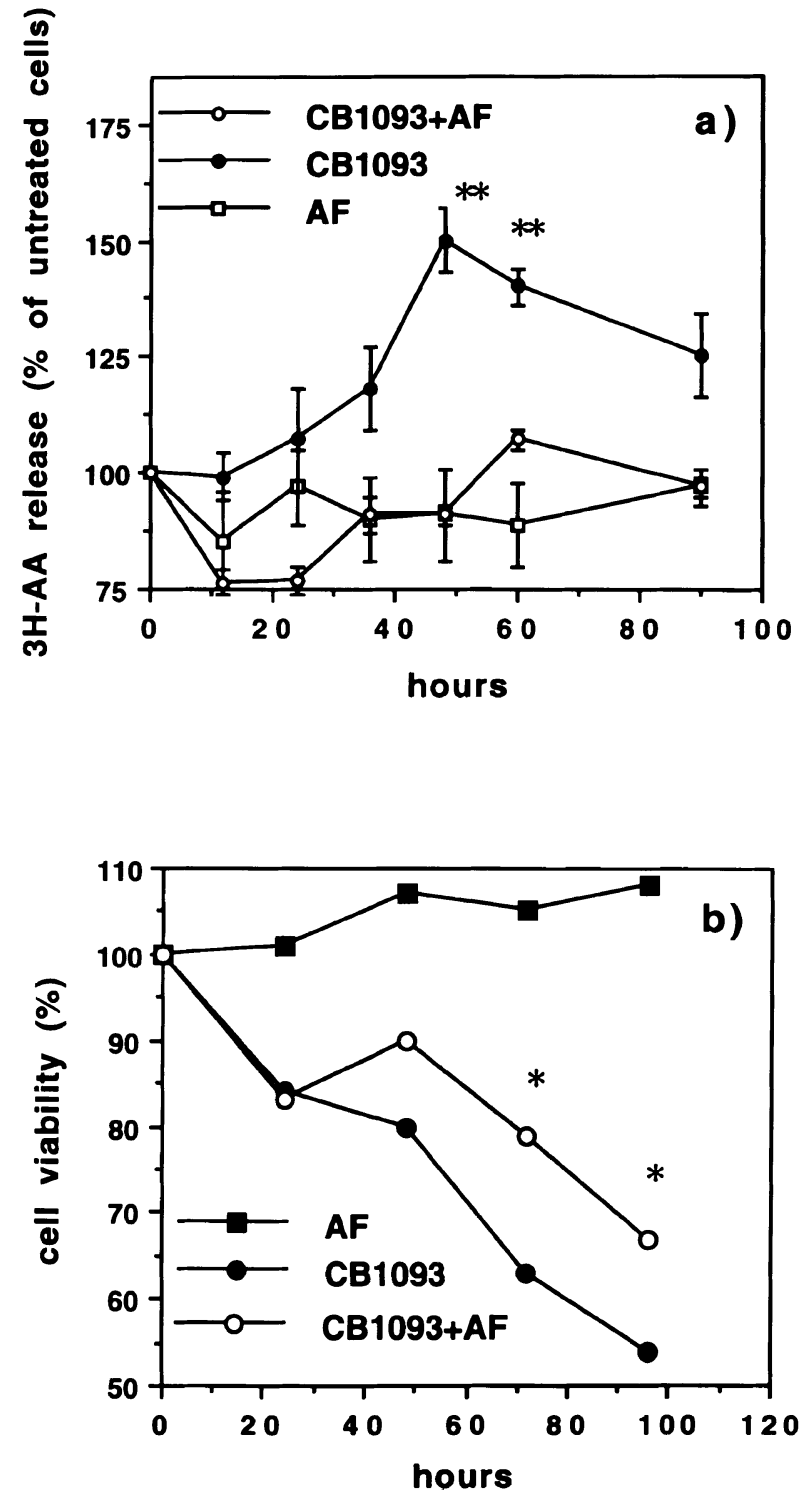

Figure 8 (a) CB1093 induces cPLA 2 activation in MCF-7 cells. MCF-7 cells were labeled with $\left[{ }^{3} \mathrm{H}\right]-\mathrm{AA}(0.3 \mu \mathrm{Ci} / \mathrm{ml})$ for $18 \mathrm{~h}$, washed extensively and incubated with or without specific inhibitor $\mathrm{AACOCF}_{3}(5 \mu \mathrm{M})$ for $3 \mathrm{~h}$ and then treated with $\mathrm{CB} 1093(50 \mathrm{nM}$ for $0-96 \mathrm{~h})$. $\mathrm{CPLA}_{2}$ activation was assessed by $\left[{ }^{3} \mathrm{H}\right]-\mathrm{AA}$ release as described in Materials and Methods. Statistical comparison between CB1093 alone and CB1093 plus AF was found to be significant at ${ }^{* *} P<0.001$. (b) Effect of $\mathrm{AACOCF}_{3}$ on $\mathrm{CB}_{1093}$-induced loss of cell viability in MCF-7 cells. Replicate cultures were assessed for cell viability by MTS assay, as described in Materials and Methods. Statistical comparison between CB1093 alone and CB1093 plus AF was found to be significant at ${ }^{*} P<0.005$. Results are the mean \pm S.D. of three replicate estimations and are representative of three separate experiments

\section{Loss of cell viability in MCF-7 cells treated with CB1093 is associated with CPLA 2 activation}

To determine if activation of $\mathrm{cPLA}_{2}$ could be involved in the induction of MCF-7 cell apoptosis induced by vitamin $D$ analogs in the absence of TNF $\alpha$, activity of this enzyme was determined in cells treated from 2-5 days with $50 \mathrm{nM}$ of CB1093. Results show that treatment with CB1093 alone increases $C P L A_{2}$ activity by 2 days of treatment and that this activation is prevented by the specific $\mathrm{CPLA}_{2}$ inhibitor $\mathrm{AACOCF}_{3}$ (Figure 8a). Furthermore, coincubation of cells with $\mathrm{CB} 1093$ and $\mathrm{AACOCF}_{3}$ led to partial protection against the loss of cell viability induced by CB1093 alone (Figure 8b). This protection was evident from $50 \mathrm{~h}$ of treatment, the time at which $\mathrm{CPLA}_{2}$ activation was observed. These findings suggest that activation of $\mathrm{CPLA}_{2}$ may play a role in vitamin D-induced apoptosis in MCF-7 breast cancer cells.

\section{Discussion}

The biologically active form of vitamin $D$, the nuclear hormone 1,25-dihydroxyvitamin $D_{3}$, is an important regulator of cell growth, differentiation and apoptosis. Actions of this hormone are mediated by activation of the vitamin D receptor (VDR), a member of the super family of nuclear receptors acting as ligand-inducible transcription factors. ${ }^{29}$ Synthetic analogs of vitamin $\mathrm{D}$ have been shown to display antiproliferative effects on breast cancer cells both in vivo and in vitro. EB1089 has been demonstrated to induce MCF-7 cell apoptosis in vitro $^{10,12,30}$ and in vivo when these cells are grown as tumor

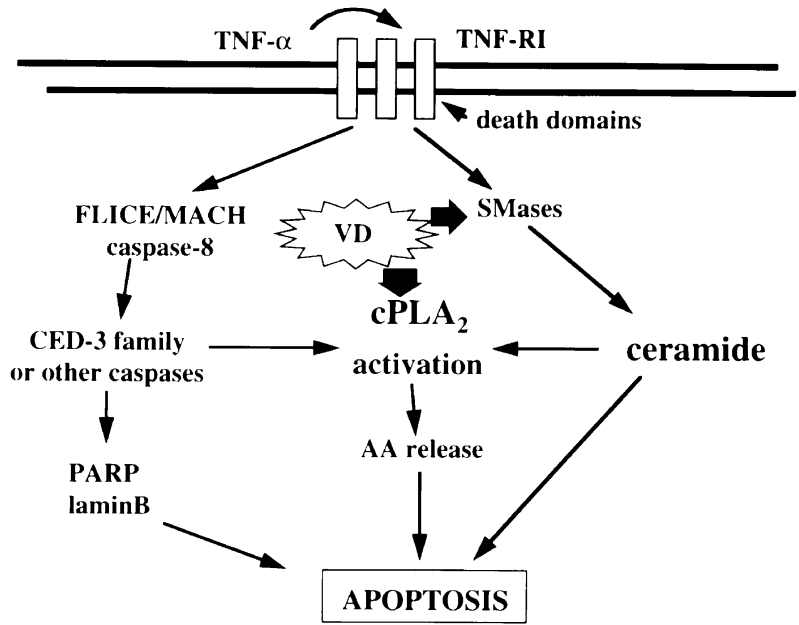

Figure 9 Proposed scheme for interaction of vitamin $D$ analogs with pathway for TNF $\alpha$-induced apoptosis in breast cancer cells. The $55 \mathrm{kDa}$ TNF receptor initiates apoptosis via formation of a death domain adaptor protein complex that links downstream to neutral sphingomyelinase ${ }^{22}$ and caspase activation leading to PARP cleavage and apoptosis. Activation of $\mathrm{CPLA}_{2}$ may be promoted via ceramide signaling ${ }^{20}$ and/or via CED-3 caspase activation. ${ }^{25}$ Arachidonic acid, generated by $\mathrm{CPLA}_{2}$ activation, can lead to loss of membrane integrity and cell death. It is suggested that vitamin $D$ analogs, through altered transcription of target genes, increase generation of ceramide and $\mathrm{CPLA}_{2}$ activation such that apoptosis can be initiated in response to suboptimal concentrations of TNF $\alpha$ 
xenografts in nude mice. ${ }^{31}$ The novel vitamin $D$ analog CB1093 has been shown to display potent antitumor effects in vivo and in vitro and its effects on induction of apoptosis are evident at concentrations approximately tenfold lower than EB1089. ${ }^{10}$ Furthermore, induction of apoptosis has been reported to be accompanied by decreased bcl-2 protein expression. ${ }^{10}$ In the present study we demonstrate that preincubation of MCF-7 cells with vitamin D analogs potentiates the effects of $\mathrm{TNF} \alpha$ on induction of apoptosis. Enhanced responsiveness was demonstrated by a reduction in time of treatment required to observe cell death and the dose of cytokine at which substantial cytotoxicity was observed. Rocker et al. ${ }^{49}$ reported a similar time course of cytotoxicity in response to cotreatment with $1,25(\mathrm{OH})_{2} \mathrm{D}_{3}$ and TNF $\alpha$ in a TNF $\alpha$-sensitive MCF-7 subclone. In contrast, no significant cytotoxicity with anti-Fas treatment was detected in both control and vitamin D analog pretreated cells. This is in agreement with other studies demonstrating little effect of antiFas in wild-type MCF-7 cells although apoptosis is achieved in cells over expressing Fas. $^{32}$ Using videomicroscopy we observed typical morphological changes associated with apoptosis, such as shrinkage and blebbing, in MCF-7 cells treated with CB1093 alone or in combination with $\mathrm{TNF} \alpha$, but these changes were less evident in cells treated with TNF $\alpha$ alone. These results correlated well with data obtained from DNA fragmentation analysis where 40\% DNA fragmentation was detected after $48 \mathrm{~h}$ exposure of CB1093-primed cells to $\operatorname{TNF} \alpha$, while the cytokine alone was able to induce only $25 \%$ DNA fragmentation for the same period of time. It has been reported that TNF $\alpha$-induced cytotoxicity in MCF-7 cells is not accompanied with typical apoptotic morphological changes, possibly due to functional deletion of the caspase- 3 gene. ${ }^{33}$ In this regard we suggest that pretreatment with vitamin $D$ analogs may potentiate TNF $\alpha$-mediated cell death in MCF-7 cells by targeting cleavage of key proteins important for maintenance of cell architecture.

Possible mechanisms by which vitamin $D$ analogs enhance responsiveness to TNF $\alpha$ may involve increased signal recognition, decreased expression of proteins which lead to TNF $\alpha$ resistance or the promotion of a common apoptotic pathway. It has been recently shown that differences in susceptibility of TNF $\alpha$-induced apoptosis among MCF-7 cells variants may be explained by differences in TNF-RI expression. ${ }^{34}$ We have been unable to observe substantial increases in the expression of the receptor for TNF $\alpha$ in response to vitamin D analogs. Using RT-PCR, we have evaluated transcripts for TNF-RI in MCF-7 cells treated with CB1093 and no marked increases were observed over a time course of 1-24 h. In contrast, treatment with the vitamin $D$ analog produced a marked induction of the 24-hydroxylase gene which previously has been shown to be a primary vitamin $D$ responding gene. ${ }^{27}$ Although there are indications that the TNF $\alpha$ gene is also a target gene for $1,25(\mathrm{OH})_{2} \mathrm{D}_{3},{ }^{35}$ promotion of apoptosis by vitamin $\mathrm{D}$ analogs does not appear to be related to increased endogenous production of TNF $\alpha$ in MCF-7 cells, as we have been unable to detect increased elaboration of TNF $\alpha$-like bioactivity in conditioned medium or substantial increases in the level of TNF $\alpha$ transcripts in response to CB1093.
Another possible mechanism by which vitamin $D$ analogs may potentiate TNF $\alpha$-induced cytotoxicity is by promotion of a common apoptotic pathway. Several intracellular pathways have been demonstrated to be involved in the TNF $\alpha$ initiated cytotoxic process, including reduction of glutathione levels, free radical generation ${ }^{36}$ and activation of the caspase system. ${ }^{37}$ TNF $\alpha$-mediated apoptosis in MCF-7 cells has been reported to be associated with a several fold accumulation of ceramide production, starting at $10-12 \mathrm{~h}$ and reaching fourfold by $24 \mathrm{~h} .{ }^{38}$ Furthermore, it has been documented that inability of $\mathrm{TNF} \alpha$ to induce ceramide formation and $\mathrm{CPLA}_{2}$ activation leads to resistance to TNF $\alpha$-mediated cell death in MCF-7 cells. ${ }^{39}$ Our present findings have shown that vitamin $D$ analogs increase responsiveness of MCF-7 cells to $\mathrm{C}_{2}$-ceramide in terms of loss of cell viability, DNA fragmentation and ceramideinduced activation of $\mathrm{CPLA}_{2}$. For all three cellular functions the dose-response curve to $\mathrm{C}_{2}$-ceramide was shifted to the left in CB1093 primed cells. Of interest are reports that $1,25(\mathrm{OH})_{2} \mathrm{D}_{3}$ promotes generation of ceramide (an increase of $40-70 \%$ after $1-2 \mathrm{~h}$ of treatment) which plays an important role in regulation of cell proliferation in $\mathrm{HaCaT}$ cells and cell differentiation in HL-60 cells respectively. ${ }^{35,40}$ If the same is true in MCF-7 cells, then pretreatment with vitamin $D$ analogs may increase intracellular ceramide to a critical level whereby active cell death can be initiated in response to sub-optimal concentrations of TNF $\alpha$.

Our studies show that TNF $\alpha$ activates $\mathrm{CPLA}_{2}$ in MCF-7 breast cancer cells. Activation of this enzyme has been shown to be essential for TNF $\alpha$ action on L929 cells as TNF $\alpha$ resistant mutants lacking $\mathrm{CPLA}_{2}$ expression displayed TNF $\alpha$ sensitivity following exogenous expression of $\mathrm{cPLA}_{2}{ }^{41}$ Inhibition of ${ }^{\mathrm{CPLA}} \mathrm{A}_{2}$ by antisense strategies rendered melanoma cells resistant to TNF $\alpha$-mediated cytotoxicity. ${ }^{28}$ A specific inhibitor of $\mathrm{CPLA}_{2}\left(\mathrm{AACOCF}_{3}\right)$ inactivates $\mathrm{CPLA}_{2}$ by competitive binding to the active site of this enzyme. ${ }^{42}$ Wissing et al. ${ }^{25}$ showed that $\mathrm{AACOCF}_{3}$ inhibits TNF $\alpha$-induced cytotoxicity in MCF-7 and WEHI cells further supporting the suggestion that $\mathrm{CPLA}_{2}$ is an essential part of the TNF $\alpha$-induced death pathway. Our results show that preincubation with $\mathrm{AACOCF}_{3}$ prevents CB1093 potentiation of $\mathrm{CPLA}$ activation. The mechanism by which $\mathrm{CPLA}_{2}$ mediates apoptosis is still unclear. Interestingly, it has been shown recently that activation of $\mathrm{cPLA}_{2}$ in TNF $\alpha$ induced apoptosis is caspase dependent. ${ }^{25}$ This group demonstrated that a specific inhibitor of the caspase-3 family (Ac-DEVD-cho) inhibited TNF $\alpha$-induced $\mathrm{CPLA}_{2}$ cleavage and $A A$ release. Using a broad spectrum caspase inhibitor ( $z-V A D-f m k$ ) we have confirmed that TNF $\alpha$-induced $\mathrm{cPLA}_{2}$ is caspase dependent. However our preliminary data show that z-VAD-fmk does not protect against CB1093-induced loss of MCF-7 cell viability, suggesting that caspases may not be involved in this signaling pathway (data are not shown). More intriguing data have been recently reported by Luschen et al. ${ }^{43}$ who have demonstrated that the presence of multiple sites of $\mathrm{cPLA}_{2}$ cleavage by several caspases may generate a variety of cleavage products, which may have different roles in inflammation or apoptosis. The observation that $\mathrm{cPLA}_{2}$ activation is caspase-dependent has prompted the 
suggestion that it must act in the final execution step of apoptosis and that $\mathrm{CPLA}_{2}$-mediated release of $\mathrm{AA}$ may disrupt the integrity of various cellular membranes. ${ }^{25}$ An alternative suggestion is that the released AA may act as a second messenger and activate other apoptosis-associated enzymes such as sphingomyelinase. ${ }^{25}$ Our observation that exogenous ceramide itself promotes activation of $\mathrm{CPLA}_{2}$ in a dose dependent manner makes this suggestion less likely. Alternatively the localization of the sphingomyelin pool in different cell compartments and gradual accumulation of ceramide in TNF $\alpha$-mediated cell death in MCF-7 cells, support the suggestion that ceramide formation might be both upstream and downstream of the caspase-3 family or acts in different stages of apoptosis. ${ }^{44}$ Ceramide is known to induce cell differentiation, cell cycle arrest or apoptosis depending on cell type and activation of other signal transduction pathways. Interestingly, vitamin D derivatives appear to modulate TNF $\alpha$ signaling to produce two distinct cell type specific effects. It has been reported that $1,25(\mathrm{OH})_{2} \mathrm{D}_{3}$ protects MG-63 osteoblasts from the cytotoxic effects of TNF $\alpha^{45}$ and $U 937$ leukemic cells induced to differentiate by pretreatment with EB1089 did not undergo apoptosis when exposed to $\operatorname{TNF} \alpha$ while uninduced control culture were susceptible to the cytotoxic effects of the cytokine. ${ }^{46}$ Of considerable interest is the recent observation in $U 937$ cells that pretreatment with $1,25(\mathrm{OH})_{2} \mathrm{D}_{3}$ inhibits both TNF $\alpha$-induced apoptosis and activation of $\mathrm{CPLA}_{2}$ in response to $\mathrm{TNF}_{\alpha}{ }^{47}$ Our present findings whereby vitamin $\mathrm{D}$ analogs potentiate $\mathrm{TNF} \alpha$ induced activation of $\mathrm{CPLA} 2$ in MCF-7 cells suggests that differential effects on $\mathrm{CPLA}_{2}$ activation may be related to the ability of vitamin $D$ derivatives to modulate TNF $\alpha$ induced apoptosis in cell-type specific manner. Furthermore we have established a system where vitamin $D$ analogs do not enhance the susceptibility of MCF-7 cells to undergo apoptosis. In agreement with recent findings that $1,25(\mathrm{OH})_{2} \mathrm{D}_{3}$ does not affect cytotoxicity induced by etoposide in MCF-7 cells, ${ }^{48}$ we have found that CB1093primed MCF-7 cells do not show enhanced sensitivity to etoposide-induced apoptosis and furthermore, etoposide does not promote $\mathrm{CPLA}_{2}$ activation (data are not shown).

In addition to promoting $\mathrm{TNF} \alpha$ and ceramide-induced apoptosis, vitamin $\mathrm{D}$ derivatives alone induce $\mathrm{CPLA}_{2}$ activation and active cell death in MCF-7 cells indicating that $\mathrm{CPLA}$ may be involved in vitamin D-induced apoptosis. However, while substantial cell death is detected in vitamin $\mathrm{D}$ pretreated cells after $18 \mathrm{~h}$ treatment with TNF $\alpha$, effects of vitamin $D$ analogs alone on apoptosis are only observed after 3-5 days of treatment. This suggests a requirement for altered expression of genes in response to these analogs and increased (or decreased) synthesis of bioactive proteins which ultimately result in the demise of the cells by apoptosis. Further studies are required to identify the nature of these primary target genes for vitamin $D$.

In summary, the results of our study indicate that synthetic analogs of vitamin $D$ potentiate the responsiveness of MCF-7 breast cancer cells to TNF $\alpha$-induced apoptosis. The relation of our results to in vivo efficacy of $\mathrm{TNF} \alpha$ in combination with vitamin D analogs warrants further investigations. Our findings further suggest that vitamin $\mathrm{D}$ analogs share a common pathway leading to cell death which involves $\mathrm{CPLA}_{2}$ activation and/or ceramide generation (Figure 9) such that apoptosis can be initiated in response to sub-optimal concentrations of TNF $\alpha$. The relationship of $\mathrm{cPLA}_{2}$ activation and ceramide generation to vitamin $\mathrm{D}$-induced apoptosis in other cell types requires further investigation.

\section{Materials and Methods}

\section{Reagents}

EB1089 (22,24-diene-24 $\alpha, 26 \alpha, 27 \alpha$-trihomo-1 $\alpha, 25$-dihydroxyvitamin $D_{3}$ ) and CB1093 (20-epi-22(S)-ethoxy-23yne-24 $\alpha, 26 \alpha, 27 \alpha$-trihomo$1 \alpha, 25$-dihydroxyvitamin $D_{3}$ ) were gifts from Dr. Lise Binderup Leo Pharmaceutical Products, Denmark. The vitamin D compounds were dissolved in ethanol and stored at $-20^{\circ} \mathrm{C}$. For use in experiments the ethanol concentration did not exceed $0.1 \%$ in tissue culture medium. Human recombinant TNF alpha (TNF $\alpha$ ), $\mathrm{C}_{2}$-ceramide, anti-Fas and $\mathrm{CPLA}_{2}$ inhibitor Arachidonyl trifluoromethylketone $\left(\mathrm{AACOCF}_{3}\right)$ were purchased from Calbiochem, UK. [ ${ }^{3} \mathrm{H}$-methyl-thymidine $(80.0 \mathrm{Ci} /$ $\mathrm{mmol})$ was purchased from Amersham and 5.6.8.9.11.12.14.15-[ $\left.{ }^{3} \mathrm{H}\right]-$ arachidonic acid $(240 \mathrm{Ci} / \mathrm{mmol})$ was obtained from New England Nuclear (Boston, MA, USA). Tissue culture media (RPMI-1640, DMEM) were obtained from Life Technologies (Paisley, Scotland).

\section{Cell cultures}

The MCF-7 human breast cancer cell line was maintained in Dulbecco's modification of Eagle's medium DMEM) supplemented with $100 \mathrm{U} / \mathrm{ml}$ penicillin, $100 \mu \mathrm{g} / \mathrm{ml}$ streptomycin and $5 \%$ fetal calf serum (FCS). In some experiments phenol-red free DMEM medium supplemented with $5 \%$ charcoal stripped FCS was used with similar results.

\section{Cell viability and DNA fragmentation assays}

Neutral red assay Neutral red is a vital dye that accumulates in the lysosomes of living, uninjured cells. Cytotoxicity of TNF $\alpha$ in control and vitamin $\mathrm{D}$ analog pretreated cultures was determined by the method of Rocker et al. ${ }^{49}$ Briefly MCF-7 cells were seeded into 24 well plates (Nunc, Oxford, UK) at a density of $2 \times 10^{4}$ cells/well in $5 \%$ FCS, DMEM and left to adhere for $4-5 \mathrm{~h}$ after which medium containing vitamin $\mathrm{D}$ analogs was added. Following a preincubation period of $24-67 \mathrm{~h}$, fresh medium containing the analogs with and without TNF $\alpha(0.2-$ $20 \mathrm{ng} / \mathrm{ml}$ ) was added and cultures were incubated for a further 18$48 \mathrm{~h}$. In some experiments, anti-Fas $(250 \mathrm{ng} / \mathrm{ml})$ was added in place of TNF $\alpha$. In other experiments, cells were switched to serum-free medium (RPMl-1640, bovine serum albumin $0.5 \mathrm{mg} / \mathrm{ml}$ and transferrin $0.01 \mathrm{mg} /$ $\mathrm{ml}$ ) and $\mathrm{C}_{2}$-ceramide was added. At the end of the incubation period, medium was removed and cells were incubated with neutral red solution (from Sigma, $40 \mu \mathrm{g} / \mathrm{ml}$ in phenol-red and serum free DMEM) for $2 \mathrm{~h}$ at $37^{\circ} \mathrm{C}$. After removal of the neutral red solution, wells were rinsed once with $1 \mathrm{ml} 4 \%$ formal saline containing $0.5 \% \mathrm{CaCl}_{2}$. Plates were inverted on paper towel to drain and $200 \mu \mathrm{l}$ of elution fluid (1\% acetic acid in $50 \%$ ethanol) was added. Following incubation at room temperature for 30 min with gentle shaking, absorbance at $550 \mathrm{~nm}$ was determined using a Titertec plate reader. The cytotoxic effect of TNF $\alpha$ was calculated as previously described. ${ }^{49}$

MTS assay Cell viability was determined by MTS dye-reduction assay measuring mitochondrial respiratory function. ${ }^{50}$ MCF-7 cells were plated in 96 well microtiter plates and treated with compounds of 
interest for various lengths of time. Cells were incubated with MTS dye (2 $\mathrm{mg} / \mathrm{ml}, 20 \mu \mathrm{l} /$ well) for $4 \mathrm{~h}$, and solubilized with 10\% SDS at room temperature for $16 \mathrm{~h}$. Absorbance was read in a Titertek plate reader at $492 \mathrm{~nm}$. The absorbance is directly related to viable cell number.

DNA fragmentation assay MCF-7 cells were incubated with $\left[{ }^{3} \mathrm{H}\right.$ methy!-thymidine $(0.5 \mu \mathrm{Ci} / \mathrm{ml})$ for $24 \mathrm{~h}$ to label DNA and then washed before exposure to the indicated agents. Cells were lysed and $\left[{ }^{3} \mathrm{H}\right.$ methyl-thymidine incorporated into both soluble and unfragmented DNA was determined by liquid scintillation counting using the formula: per cent fragmented $D N A=100 \times$ (fragmented/fragmented+intact chromatin) as previously described. ${ }^{51}$

Videomicroscopy In order to further validate the time course of induction of apoptosis by combinations of $\mathrm{TNF} \alpha$ and vitamin $\mathrm{D}$ analogs, videomicroscopy was used to directly observe cell death. MCF-7 cells were plated in T25 flasks and treated for $42 \mathrm{~h}$ with ethanol vehicle (control) or $25 \mathrm{nM} \mathrm{CB1093}$ and then TNF $\alpha(10 \mathrm{ng} / \mathrm{ml}$ final concentration) was added to the flasks. Four hours after addition of TNF $\alpha$ typical fields from CB1093/TNF $\alpha$ and control/TNF $\alpha$ treated cultures were photographed over a $48 \mathrm{~h}$ period at $1 / 150$ normal speed with a time-lapse videorecorder. After this period, typical fields from control and CB1093 treated cultures in the absence of $\mathrm{TNF} \alpha$ were similarly photographed.

\section{Detection of TNF $\alpha$, TNF-RI and 24-hydroxylase mRNA by semi-quantitative PCR}

MCF-7 cells were maintained in phenol red-free DMEM supplemented with $2.5 \%$ charcoal-treated FCS. Cultures at $70 \%$ confluence were treated with vitamin $D$ analogs or ethanol vehicle $(0.1 \%)$ for $1-24 \mathrm{~h}$, then collected and total RNA isolated with Trizol Reagent (Life Technologies, Paisley, Scotland). First strand cDNA synthesis was performed on $2 \mu \mathrm{g}$ total RNA. Reverse transcription was carried out at $37^{\circ} \mathrm{C}$ for $60 \mathrm{~min}$ in a final volume of $40 \mathrm{ml}$ in the presence of $0.25 \mu \mathrm{M}$ oligo dT15-primer, $0.5 \mathrm{mM}$ dNTPs, $5 \mathrm{mM}$ DTT, $1 \mathrm{U}$ RNasin, $5 \mathrm{U}$ MMLV-RT (Llfe Technologies) and $1 \times$ first strand buffer $(0.05 \mathrm{M}$ Tris$\mathrm{HCl}, \mathrm{pH} 8.3,0.075 \mathrm{M} \mathrm{KCl}, 3 \mathrm{mM} \mathrm{MgCl} 2$ ). The cDNA initially generated was precipitated and then dissolved in water to give a final volume of $200 \mathrm{ml}$ and of this $5 \mathrm{ml}$ was taken for use in PCR. The following oligonucleotide primers were used to represent: TNF- $\alpha+; 5^{\prime}$-TCTTGCACAGTGGACCGGGA-3'; TNF $\alpha-; 5^{\prime}$-CACCGTTGGTAGCGATACAT3'; TNF-RI-; 5'-ATTTGCTGTACCAAGTGCCACAAAGGAACC-3'; TNF-RI; 5'-GTCGATTTCCCACAAAAACAATGGAGTAGAGC-3'; 24hydroxylase+; 5'-CTGCTGCAGATTCTCTGGA-3'; 24-hydroxylase -; $5^{\prime}$-ATGATGAAGTTCACAGCTTC-3' and $\beta_{2}$ microglobulin+; $5^{\prime}$ CCCCCACTGAAAAAGATGAGTATGCCTG-3'; $\beta_{2}$ microglobulin -; 5'-CCTGTGGAGCAACCTGCTCAGATACCATC-3'.

Primers were $5^{\prime}$ end labeled with ${ }^{32} \mathrm{PdATP}$. The following PCR conditions were used for TNF $\alpha$, 24-hydroxylase and $\beta_{2}$ microglobulin; $94^{\circ} \mathrm{C}$ for $5 \mathrm{~min}, 94^{\circ} \mathrm{C}$ for $1 \mathrm{~min}, 58^{\circ} \mathrm{C}$ for $2 \mathrm{~min}, 72^{\circ} \mathrm{C}$ for $300 \mathrm{~s}$ for 40 cycles then $94^{\circ} \mathrm{C}$ for $10 \mathrm{~s}, 58^{\circ} \mathrm{C}$ for $1 \mathrm{~min}, 72^{\circ} \mathrm{C}$ for $30 \mathrm{~s}$ for 30 cycles and only 22 cycles for $\beta_{2}$ microglobulin, then $72^{\circ} \mathrm{C}$ for $10 \mathrm{~min}$. For TNF$\mathrm{RI}$ an annealing temperature of $55^{\circ} \mathrm{C}$ was used. Amplified TNF $\alpha$, TNF$\mathrm{RI}, 24$-hydroxylase or $\beta_{2}$ microglobulin mRNA was resolved on a $5 \%$ nondenaturing polyacrylamide gel in 0.5 TBE [ $45 \mathrm{mM}$ Tris, $45 \mathrm{mM}$ boric acid, $1 \mathrm{mM}$ EDTA ( $\mathrm{pH}$ 8.3)]. Following autoradiography, the bands representing the radioactive free probe and the radioactive TNF $\alpha$, TNF-RI, 24-hydroxylase/ $\beta_{2}$ microglobulin probes were localized, excised and assayed directly by scintillation counting. The amount of TNF $\alpha$, TNF-RI and 24-hydroxylase mRNA was normalized to $\beta_{2}$ microglobulin mRNA and fold induction of response was calculated as the ratio of ligand stimulated cells to that of vehicle treated controls.

\section{Determination of biological activity in culture supernatants}

MCF-7 cells were plated in 24-well plates and treated with ethanol vehicle, $50 \mathrm{nM}$ CB1093, $0.1 \mathrm{ng} / \mathrm{ml} \mathrm{TNF} \alpha$ or CB1093 together with TNF $\alpha$ for 3 days. Media were removed, the cells washed three times in serum-free medium and then $1 \mathrm{ml}$ of either medium containing CB1093 and/or TNF $\alpha$ at these same concentrations or fresh medium without these agents was added to the cultures. Media were conditioned for 2 days before being aspirated, centrifuged at $8000 \times \mathrm{g}$ and supernatants stored at $-20^{\circ} \mathrm{C}$ before assay. TNF $\alpha$ bioactivity was quantified without further dilution in a $22 \mathrm{~h}$ cytotoxicity assay using WEHI 164 clone 13 cells as previously described. ${ }^{52}$ The detection limit of this assay was $250 \mathrm{fg} / \mathrm{ml}$.

\section{Activation of $\mathrm{CPLA} \mathrm{A}_{2}$}

Measurement of $\left[{ }^{3} \mathrm{H}\right]$-arachidonic acid (AA) release from MCF-7 breast cancer cells was determined as described by Jaattela et al. ${ }^{32}$ Briefly, MCF-7 cells seeded in 24 well plates $\left(2 \times 10^{4} /\right.$ well in $\left.0.5 \mathrm{ml}\right)$ and primed with or without $\mathrm{CB} 1093$ for $24-48 \mathrm{~h}$ were labeled with $0.3 \mu \mathrm{Ci} /$ $\mathrm{ml}$ 5.6.8.9.11.12.14.15-[ $\left.{ }^{3} \mathrm{H}\right]$-arachidonic acid and incubated at $37^{\circ} \mathrm{C}$ for the final $18 \mathrm{~h}$ of treatment. The unincorporated $\left[{ }^{3} \mathrm{H}\right]-\mathrm{AA}$ was removed by washing three times with serum-free medium. Fresh medium was added containing graded concentrations of TNF $\alpha$ (0.1$20 \mathrm{ng} / \mathrm{ml}$ ) or vehicle for $22 \mathrm{~h}$. In some experiments cells were switched to serum-free medium and $\mathrm{C}_{2}$-ceramide $(0.5-20 \mu \mathrm{M})$ was added for $5 \mathrm{~h}$. In experiments using $\mathrm{AACOCF}_{3}$ inhibitor, cells were first pretreated for $3 \mathrm{~h}$ with $\mathrm{AACOCF}_{3}$ and then exposed to the drugs. Media were removed, centrifuged at $2000 \times \mathrm{g}$ for $5 \mathrm{~min}$ and $0.5 \mathrm{ml}$ of supernatant processed for liquid scintillation counting. Cells were removed by trypsinization, and cell pellets solubilized in $0.5 \mathrm{M}$ sodium hydroxide and assessed for radioactivity. The percentage of release of $\left[{ }^{3} \mathrm{H}\right]-\mathrm{AA}$ was calculated by the formula $[\mathrm{S} /(\mathrm{S}+\mathrm{P})] \times 100$ where $\mathrm{S}$ and $\mathrm{P}$ represent radioactivity detected in $0.5 \mathrm{ml}$ of supernatant and solubilized cell pellet respectively. Non enzymic release of $\left.{ }^{3} \mathrm{H}\right]-\mathrm{AA}$ from prelabeled cells, frozen at $-80^{\circ} \mathrm{C}$ and thawed at room temperature, was less than $10 \%$ in all experiments. ${ }^{47}$ Results were expressed as a per cent of $\left[{ }^{3} \mathrm{H}\right]-\mathrm{AA}$ release in nontreated cells (accepted as 100\%).

\section{Statistical analysis}

Statistical analysis was performed using unpaired Student's $t$-test or analysis of ANOVA using the Stat-view-4 software package (Apple Macintosh). $P<0.05$ was considered statistically significant.

\section{Acknowledgements}

We would like to thank Tim Arnett for help with videomicroscopy and Dr. L Binderup (LEO Pharmaceutical Products, Denmark) for CB1093 and EB1089. This study was supported by the Association for International Cancer Research.

\section{References}

1. Colston KW, Colston MJ and Feldman D (1981) 1,25-dihydroxyvitamin $D_{3}$ and malignant melanoma: the presence of receptors and inhibition of cell growth in culture. Endocrinology 108: 1083-1086

2. Abe E, Miyaura C, Sakgami H, Takeda M, Konno K, Yamazaki T and Suda T (1981) Differentiation of mouse myeloid leukaemia cells induced by 1,25 dihydroxyvitamin $D_{3}$. Proc. Natl. Acad. Sci. USA 78: 4990-4994 
3. Frampton RJ, Omond SA and Eisman JA (1983) Inhibition of human cancer cell growth by 1,25-dihydroxyvitamin $D_{3}$ metabolites. Cancer Res. 43: 4443-4447

4. Smith EL, Walworth NC and Holick F (1986) Effect of 1,25-dihydroxyvitamin $D_{3}$ on the morphologic and biochemical differentiation of cultured human epidermal keratinocytes grown in serum free medium. J. Invest. Dermatol. 86: 709-714

5. Binderup L and Godtfedsen OW (1997) Development of new vitamin D analogs. In: Vitamin D, Feldman D, Glorieux FH and Pilce J, eds (San Diego: Academic Press) pp. $1027-1043$

6. Bouillon R, Okamura WH and Norman AW (1995) Structure function relationships in the vitamin D endocrine system. Endocr. Rev. 16: 200-257

7. Mathiasen IS, Colston KW and Binderup L (1993) EB1089, a novel vitamin D analogue, has strong antiproliferative and differentiation inducing effects on cancer cells. J. Steroid Biochem. Molec. Biol. 46: 365-371

8. Elstner E, Linker-Israeli M, Said J, Umiel J, de Vos S, Shintaku IP, Heber D, Binderup L, Uskokovic M and Koeffler HP (1995) 20-epi-vitamin D ${ }_{3}$ analogues; a novel class of potent inhibitors of proliferation and inducers of differentiation of breast cancer cell lines. Cancer Res. 55: 2822-2830

9. Colston KW, Mackay AG, James SY, Binderup L, Chander S and Coombes RC (1992) EB1089: a new vitamin D analogue that inhibits the growth of breast cancer cells in vivo and in vitro. Biochem. Pharmacol. 44: 2273-2280

10. Danielsson C, Mathiasen IS, James SY, Nayeri S, Bretting C, Mork Hansen C, Colston KW and Carlberg C (1997) Sensitive induction of apoptosis in breas cancer cells by a novel 1,25 -dihydroxyvitamin $\mathrm{D}_{3}$ analogue is related to promoter selectivity. J. Cell. Biochem. 66: 552-565

11. James SY, Mackay AG and Colston KW (1995) Vitamin D derivatives in combination with 9-cis retinoic acid promote active cell death in breast cancer cells. J. Mol. Endocrinol. 14: 391-394

12. Simboli-Campbell M, Narvaez CJ, Tenniswood M and Welsh J (1996) 1,25dihydroxyvitamin $D_{3}$ induces morphological and biochemical markers of apoptosis in MCF-7 breast cancer cells. J. Steroid Biochem. Molec. Biol. 58: 367-376

13. Elstner E, Linker-Israel M, Umiel T, Le J, Grillier I, Said J, Shintaku IP, Krajewski S, Reed JC, Binderup L and Koeffler HP (1996) Combination of a potent 20-epivitamin $\mathrm{D}_{3}$ analogue ( $\mathrm{KH} 1060$ ) with 9-cis-retinoic acid irreversibly inhibits clonal growth, decreases bcl-2 expression and induces apoptosis in $\mathrm{HL}-60$ leukaemic cells. Cancer Res. 56: 3570-3576

14. Vandewalle B, Hornez L, Wattez N, Revellion F and Lefebvre J(1995) Vitamin $D_{3}$ derivatives and breast cancer cell growth:effect on intracellular calcium and apoptosis. Int. J. Cancer 61: 806-811

15. Lewis M, Tartaglia LA, Lee A, Bennett GL, Rice GC, Wong GHW, Chen W and Goeddel DV (1991) Cloning and expression of cDNAs for two distinct murine tumor necrosis factor receptors demonstrate one receptor is species specific. Proc. Natl. Acad. Sci. 88: 2830-2834

16. Creasey AA, Yamomoto R and Vitt CR (1987) A high molecular weigh component of the human tumor necrosis factor receptor is associated with cytotoxicity. Proc. Natl. Acad. Sci. USA. 84: 3293-3297

17. Hsu H, Xiong J and Goeddel DV (1995) The TNFR1-associated protein FADD signals cell death and NF- $k$ B activation. Cell 81: 495-504

18. Chinnaiyan AM, O'Rourke K, Tewai M and Dixit V (1995) FADD, a novel death domain-containing protein, interacts with the death domain of FAS and initiates apoptosis. Cell 81: 505-510

19. Haimovitz-Friedman A, Kan C, Ehleiter D, Persaud RM, Fuks Z and Kolesnick R (1994) lonizing radiation acts on cellular membranes to generate ceramide and initiate apoptosis. J. Exp. Med. 180: 525-535

20. Wiegmann K, Schultz S, Machleidt T, Witte D and Kronke M (1994) Functional dichotomy of neutral and acidic sphingomyelinases in TNF signalling. Cell 78 $1005-1015$

21. Obeid LM, Linardic CM, Karolak LA and Hannun YA (1993) Program cell death induced by ceramide. Science 259: 1769-1771

22. Liu B, Andrieu-Abadie N, Levade T, Zhang P, Obeid L and Hannun $Y$ (1998) Glutathione regulation of neutral sphingomyelinase in TNF $\alpha$-induced cell death. J. Biol. Chem. 273: 11313-320

23. Kashiwagi M, Friess H, Uhl W, Graber H, Duarte H, Zimmermann A and Buchier $M$ (1998) Phospholipase $A_{2}$ isoforms are altered in chronic pancreatitis. Ann. Surgery 227: 220-228

24. Tan X and Wang J (1998) The caspase-RB connection in cell death. Trends in Cell Biology 9: $116-120$
25. Wissing D, Mousitzen H, Egeblad M, Poirer GG and Jaattela M (1997) Involvement of caspase dependent activation of cytosolic phospholipase $A_{2}$ in tumor necrosis factor-induced apoptosis. Proc. Natl. Acad. Sci. USA. 94: 50735078

26. QiuZ, Gijon M, de Carvalho M, SpencerD and Leslie C (1998) The role of calcium and phosphorylation of cytosolic phospholipase A2 in regulating arachidonic acid release in macrophages. J. Biol. Chem. 273: 8203-8211

27. Chen Kand DeLuca HF (1995) Cloning of the human 1,25 -hydroxyvitamin $D_{3} 24$ hydroxylase gene promoter and identification of two vitamin $D$ responsive elements. Biochim. Biophys. Res. Acta. 1263: 1-9

28. Voelkel-Johnson C, Thorne TE and Laster SM (1996) Susceptibility to TNF $\alpha$ in the presence of inhibitors of transcription or translation is dependent on the activity of cytosolic phospholipase $A_{2}$ in human melanoma tumor cells. J. Immunol. 56: 201-207

29. Carlberg C (1996) The concept of multiple vitamin D signaling pathways. J. Invest. Dermatol. Symp. Proc. 1: 10-14

30. James SY, Mackay AG and Colston KW (1996) Effects of 1,25 dihydroxyvitamin $D_{3}$ and its analogues on induction of apoptosis in breast cancer cells. J. Steroid Biochem. Molec. Biol. 58: 395-401

31. VanWeelden K, Flanagan L, Binderup L, Tenniswood M and Welsh J (1998) Apoptotic regression of MCF-7 xenografts in nude mice treated with vitamin $D$ analogue EB1089. Endocrinol. 139(4): 2102-2110

32. Jaattela M, Benedict M, Tewari M, Shayman JA and Dixit V (1995) Bcl-xL and bcl2 inhibit TNF $\alpha$ and Fas-induced apoptosis and activation of $\mathrm{CPLA}_{2}$ in breast carcinoma cells. Oncogene 10: 2297-2305

33. Janicke R, Sprengart M, Wati M and Porter A (1998) Caspase-3 is required for DNA fragmentation and morphological changes associated with apoptosis. J. Biol. Chem. 273: 9357-9360

34. Burow M, Weldon C, Tang V, Navar G, Krajewski, Reed J, Hammond T, Clejan S and Beckman B (1998) Differences in susceptibility to TNF $\alpha$-induced apoptosis among MCF-7 breast cancer cell variants. Canc. Res. 58: 4940-4946

35. Geilen CC, Bektas M, Wieder T, Kodelja V, Goerdt S and Orfanos CE (1997) 1,25-dihydroxyvitamin $\mathrm{D}_{3}$ induces sphingomyelin hydrolysis in $\mathrm{HaCaT}$ cells via TNF $\alpha$. J. Biol. Chem. 272: 8997-9001

36. Goossens V, Grooten J, De Vos K and Fiers W (1995) Direct evidence for TNF $\alpha$ induced mitochondrial reactive oxygen intermediates and their involvement in cytotoxicity. Proc. Natl. Acad. Sci. USA. 92: 8115-8119

37. Tewari M and Dixit V (1995) Fas and TNF $\alpha$-induced apoptosis is inhibited by the poxyvirus crmA gene product. J. Biol. Chem. 270: 3255-3260

38. Dbaido G, Perry D, Gamard C, Platt R, Poirier G, Obeid L and Hannun Y (1997) Cytokine response modifier $\mathrm{A}(\mathrm{CrmA})$ inhibits ceramide formation in response to TNF $\alpha$ : CrmA and Bcl-2 target distinct components in the apoptotic pathway. J. Exp. Med. 185: $481-490$

39. Cai Z, Bettaieb A, El Mahdani N, Legres L, Stancou R, Masliah J and Chouaib S (1997) Alteration of the sphingomyelin/ceramide pathway is associated with resistance of MCF-7 cells to TNF $\alpha$-mediated cytotoxicity. J. Biol. Chem. 272: 6918-6926

40. Okazaki T, Bielawska A, Bell R and Hannun Y (1990) Role of ceramide as a lipid mediator of 1,25-dihydroxyvitamin $\mathrm{D}_{3}$-induced $\mathrm{HL}$-60 cell differentiation. J. Biol. Chem. 265: 15823-15831

41. Hayakawa M, Ishida N, Takeuchi K, Shibamoto S, Hori T, Oku N, Ito N and Tsujimoto M (1993) Arachidonic acid- selective $\mathrm{CPLA}_{2}$ is crucial in the cytotoxic action of TNF $\alpha$. J. Biol. Chem. 268: 11290-11295

42. Bartoli F, Li H, Chomashch F, Gelb M, Jain M and Apitz-Castro A (1994) Tight binding inhibitors of $85 \mathrm{kDa} \mathrm{PLA} 2$ but not $14 \mathrm{kDa} C P L A_{2}$ inhibit release of free arachidonate in thrombin-stimulated human platelets. J. Biol. Chem. 269: $15625-15630$

43. Luschen S, Ussat S, Kronke M and Adam-Klages (1998) Cleavage of human cytosolic phospholipase $A_{2}$ by caspase-1 (ICE) and caspase-8 (FLICE). Biochim. Biophys. Res. Acta. 253: 92-98

44. Haimovitz-Friedman A, Kolesnick R and Fuks Z (1998) Ceramide signaling in apoptosis. Brit. Med. Bull. 53: 539-553

45. Welsh $\mathrm{J}$ and Jones WA (1997) 1,25-Dihydroxyvitamin $\mathrm{D}_{3}$ protects MG-63 osteoblasts from TNF $\alpha$ and ceramide induced apoptosis. In: Vitamin D: chemistry, biology and clinical applications of steroid hormone. Norman AW, Bouillon R and Thomasseti M (eds.). University of California, Riverside. pp. 405 
46. James SY and Colston K (1997) Differential induction of apoptosis in leukemia cells by vitamin D derivatives, retinoids and TNF $\alpha$. In: Vitamin D: chemistry, biology and clinical applications of steroid hormone. Norman AW, Bouillon R and Thomasset M (eds.). University of California, Riverside. pp 481

47. Wu Y, Jiang X, Lillington D, Allen P, Newland A and Kelsley S (1998) 1,25Dihydroxyvitamin $D_{3}$ protects human leukemic cells from TNF $\alpha$-induced apoptosis via inactivation of $c P L A_{2}$. Can. Res. 58: 633-640

48. Ravid A, Rocker D, Machlenkin A, Rotem C, Hochman A, Kessler-Icekson G, Liberman $U$ and Koren $R$ (1999) 1,25-dihydroxyvitamin $D_{3}$ enhances susceptibility of breast cancer cells to doxirubicin-induced oxidative damage. Cancer Res. 59: 862-867

49. Rocker D, Ravid A, Liberman UA, Garach-Jehoshua O and Koren R (1994) 1,25dihydroxyvitamin $\mathrm{D}_{3}$ potentiates the cytotoxic effect of TNF $\alpha$ on human breast cancer cells. Mol. Cell. Endocrinol. 106: 157-162
50. Cory AH, Owen TC, Barltrop JA and Cory JG (1991) Use of an aqueous soluble tetrazolium/formazan assay for cell growth assays in culture. Cancer Comm. $3(7): 207-212$

51. Duke RC and Cohen JJ (1992) In: Current Protocols in Immunology (suppl.3) Coligan JE, Kruisbeek AM, Margulies DH, Shevach EM and Strober W (eds.) New York: Green Wiley 3.17.1-3.17.16

52. EspevikT and Nissen-MeyerL (1986) A highly sensitive cell line, WEHI 164 clone 13 , for measuring cytotoxic factor/TNF from human monocytes. J Immunol. Methods 95: 99-105 